\title{
Ischemia-reperfusion histopathology alterations of the rabbit intestinal wall with and without ischemic preconditioning ${ }^{1}$
}

\author{
Alterações histopatológicas da parede intestinal de coelhos na isquemia-reperfusão com e sem \\ precondicionamento isquêmico
}

\begin{abstract}
Otoni Moreira Gomes ${ }^{\mathrm{I}}$, Geraldo Brasileiro Filho" ${ }^{\mathrm{II}}$, Rodrigo Lolli Almeida Salles ${ }^{\mathrm{III}}$, Rafaela Ervilha Linhares ${ }^{\mathrm{III}}$, Maria Cristina Nazar $^{\text {IV }}$, Luiz Alberto Bonjardim Porto ${ }^{\mathrm{III}}$, Rafael de Mattos Paixãov ${ }^{\mathrm{V}}$ Marcelo Heller Miranda ${ }^{\mathrm{VI}}$

${ }^{1}$ Research performed at Laboratory of Experimental Surgery, School of Medicine, Federal University of Minas Gerais (UFMG) and Experimental Research Laboratory Sao Francisco de Assis Truth is Jesus Cardiovascular Foundation, Belo Horizonte-MG, Brazil.

${ }^{I}$ Full Professor, Department of Surgery, School of Medicine, UFMG, Scientific Director Sao Francisco de Assis Truth is Jesus Cardiovascular Foundation, Belo Horizonte-MG, Brazil. Main author: research development drafting, analysis and interpretation of data, drafting of the manuscript, critical revision of the manuscript.

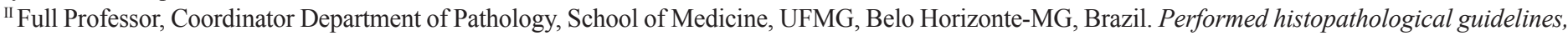
examination and critical analysis support.

III Graduate student, School of Medicine, UFMG, Belo Horizonte-MG, Brazil. Participated in study design, acquisition of data and technical support

${ }^{\text {IV }}$ Physician, National University of Tucuman - Tucuman, Argentina. Participated in study design, acquisition of data and technical support.

${ }^{v}$ Assistant Professor, Coordinator, Surgical Technique Division, Surgery Department, School of Medicine, UFMG, Belo Horizonte-MG, Brazil. Provided institutional support for the research development.

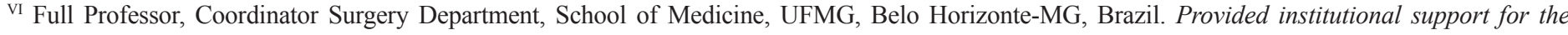
research development.
\end{abstract}

\begin{abstract}
Purpose: To evaluate the histopathology alterations of the intestinal mucosa of rabbits submitted to mesenteric artery ischemia and reperfusion with and without ischemic preconditioning. Methods: Two groups of ten male New Zealand white rabbits body (weight 2.23.0 , average $2.5 \mathrm{~kg}$ ). For mesenteric ischemia induction in all animals the small bowel and mesentery were cut $30 \mathrm{~cm}$ and $60 \mathrm{~cm}$ far from the gastroduodenal pyloric transition before the proximal mesenteric artery occlusion. In the Group 1 animals, the proximal mesenteric artery was occluded for $45 \mathrm{~min}$ with an atraumatic vascular clamp, followed by reperfusion for $30 \mathrm{~min}$. In the Group 2 the 45 min ischemic phase was preceded by three cycles of ischemia ( 2 minutes each) alternated with three cycles of reperfusion ( 2 minutes each). For istopathology study small bowel biopsies were obtained before ischemia (control), after $45 \mathrm{~min}$ of mesenteric ischemia and at $30 \mathrm{~min}$. of mesenteric artery reperfusion. Results: In the Group I animals, the followings histopathology grade results were observed: t1, mean 2,8; 2 , mean 3,3. Using the Kruskal-Wallis non-parameter test, differences between $\mathrm{t} 0$ and $\mathrm{t} 1$ and $\mathrm{t} 0$ and $\mathrm{t} 2$ were significants ( $\mathrm{p}<0.05$ ), but not significant between $\mathrm{t} 1$ and $\mathrm{t} 2$ ( $\mathrm{p}>0.05)$. In the Group 2 animals histopathology grade results were: $\mathrm{t} 1$ mean 2,6 and $\mathrm{t} 2$, mean 2,1 . Differences between $\mathrm{t} 0$ and $\mathrm{t} 1$, $\mathrm{t} 0$ and $\mathrm{t} 2$ were significant $(\mathrm{p}<0.05)$. It was not observed differences $(\mathrm{p}>0.05)$ between results of $\mathrm{t} 1$ in both groups but histopathology injury observed in Group 1 t2 biopsies were higher $(\mathrm{p}<0.05)$ than observed in the same period (t2) of Group 2 animals. Conclusion: Microscopic examination of the biopsies revealed significant evidence of preconditioning protection against small bowel wall ischemia-reperfusion injury.
\end{abstract}

Key words: Mesenteric Vascular Occlusion. Ischemic Preconditioning. Animal Experimentation. Rabbits.

\section{RESUMO}

Objetivo: Avaliar as alterações histopatológicas da mucosa intestinal de coelhos submetidos a isquemia-reperfusão com e sem precondicionamento isquêmicol. Métodos: Foram estudados dois grupos de dez coelhos Nova Zelândia machos com pesos variáveis entre 2,2 e 3,0 kg (média de 2,5 kg) de peso corpóreo. Para indução da isquemia, em todos os animais, o intestino delgado e o mesentério foram seccionados $30 \mathrm{~cm}$ e $60 \mathrm{~cm}$ após a transição pilórica gastroduodenal, antes da oclusão da artéria mesentérica cranial. Nos animais do Grupo 1, a artéria mesentérica proximal foi ocluida por pinçamento atraumático durante 45 min., seguido de reperfusão por 30 min. No Grupo 2, foi realizado precondicionamento por três ciclos de 2 min. de oclusão mesentérica intercalados com três ciclos de 2 min. de reperfusão, seguido de oclusão mantida por 45 min e reperfusão de 30min. como no Grupo I. Para estudo histopatológico, foram obtidas biópsias da parede intestinal antes da isquemia ( $\mathrm{t}_{0}$-controle), após $45 \mathrm{~min}$. de isquemia $\left(\mathrm{t}_{1}\right)$ e após 30 min. de reperfusão ( $\mathrm{t}_{2}$. Resultados: No Grupo I foram observados os seguintes graus de lesões: $\mathrm{t} 1$, média de 2,8 e t2, média 3,3, Foram significantes as diferenças entre t0 e t1 e t0 e t2, mas não foram significantes as variações entre $\mathrm{t} 1$ e $\mathrm{t} 2$ ( $>>0,05)$. No Grupo 2, obteve-se em t1, média de 2,6 e t2, média 2,1. Foram 
significantes $(p<0,05)$ as diferenças entre $\mathrm{t} 0$ e $\mathrm{t} 1$, t 0 e $\mathrm{t} 2$ e entre $\mathrm{t} 1$ e $\mathrm{t} 2$. . Não ocorreu diferença significante $(\mathrm{p}>0,05)$ entre os resultados de t1 nos dois Grupos, mas foram significantes $(\mathrm{p}<0,05)$ as diferenças entre os resultados histopatológicos das biopsias de $\mathrm{t} 2$ dos $\mathrm{Grupos} 1$ e 2. Conclusão: O precondicionamento isquêmico reduziu significantemente a degeneração histopatológica determinada pela reperfusão pós-isquêmica da parede intestinal.

Descritores: Oclusão Vascular Mesentérica. Precondicionamento Isquêmico. Experimentação Animal. Coelhos.

\section{Introduction}

In 1986, Parks and Granger ${ }^{1}$ and Murry et al. ${ }^{2}$ demonstrated by the first time that reperfusion can be more harmful than ischemia separately and the phenomenon of myocardial protection by the ischemic preconditioning with reduction of the myocardium ischemia-reperfusion injury in dogs. Yellon et al. ${ }^{3}$ demonstrated that the ischemic preconditioning protection also occurs in the human myocardium which raised a great interest extending this study also to other organs, with the landmark study by Hotter et $a l .{ }^{4}$ and more recently Santos et $a l .{ }^{5}$ confirming the ischemic preconditioning protection Santos et al. ${ }^{4}$ demonstrating the ischemic preconditioning protection of the small bowel of rats. Nowadays the ischemia-reperfusion stress is confirmed to affect with different intensity different animal species but with still little reports in the literature regarding rabbit intestinal mucosa response $\mathrm{e}^{5}$.

The objective of this study is to evaluate the ischemic preconditioning effect in the protection of the histopathology lesions of the intestinal mucosa of rabbits submitted to mesenteric ischemia considering the particular anatomy standard ${ }^{6}$ of the collateral mesenteric circulation in these animals.

\section{Methods}

This study was approved by the Ethics Committee for Animal Experimentation of our institutions and was conducted according to the guidelines for animal experimentation of the Brazilian College on Animal experimentationTwo groups of ten male New Zealand white rabbits body (weight 2.2-3.0, average 2.5 $\mathrm{kg}$ ) were used in this study. After an overnight fast with unrestricted access to water, the animals were anesthetized with muscle injections of xilazine $(15 \mathrm{mg} / \mathrm{kg} \mathrm{bw})$ and ketamine $(25 \mathrm{mg} / \mathrm{kg} \mathrm{bw})$ repeated as necessary to maintain an adequate anesthetic plane. For mesenteric ischemia induction in all animals the small bowel and mesentery were cut $30 \mathrm{~cm}$ and $60 \mathrm{~cm}$ far from the gastroduodenal pyloric transition before the proximal mesenteric artery occlusion.

In the Group 1 animals, the proximal mesenteric artery was occluded for $45 \mathrm{~min}$ with an atraumatic vascular clamp, followed by reperfusion for $30 \mathrm{~min}$.

In the Group 2 the 45 min ischemic phase was preceded by three cycles of ischemia ( 2 minutes each) alternated with three cycles of reperfusion ( 2 minutes each). In both groups small bowel biopsies were obtained before ischemia (t1- control), after $45 \mathrm{~min}$ of mesenteric ischemia (t2) and at $30 \mathrm{~min}$. of mesenteric artery reperfusion $(\mathrm{t} 3)$.

Between surgical interventions, the midline incision was sutured to minimize fluid losses. The animals were sacrificed with lethal intravenous dose of anesthetics.

The histopathology study was performed in the Pathology Anatomy Laboratory of the Minas Gerais Federal University School of Medicine and results described according to the following classification ${ }^{7}$, modified from Chiu, McArdle, Brown et al. ${ }^{8}$ classification in rats: Grade 0: Normal mucosa histology; Grade 1: Small cytology alterations in the cell structure representation. Increased leucocytes presence and space widening between villosities; Grade 2: Cell alterations with focused lesions and presence of some cell lysis. There are destructions of the the villosities in at most $25 \%$ of their extension; Grade 3: Besides the cytology alterations, there are structural lesions in intermediate extension. Presence of dilated capillaries and higher quantity of inflamed cells. The destruction should be between $25 \%$ and $50 \%$ of the villosities extension; Grade 4: Structural destruction of the villosities, only traces of some villosities, formed by inflamed cells and necrotic material, with hemorrhage and basal glandular ulceration. The destruction should be between $50 \%$ and $75 \%$ of the villosities extension; Grade 5: destruction of all the mucosa, no glandular structure can be seen, only the amorphous material laying on the sub-mucosa tissue. The destruction should be between $75 \%$ and $100 \%$ of the villosities extension (Figure 1).

Results are reported as mean \pm standard deviation (SD). The Kruskal-Wallis non parametric method was employed with statistical significance set when $\mathrm{p}<0.5$.

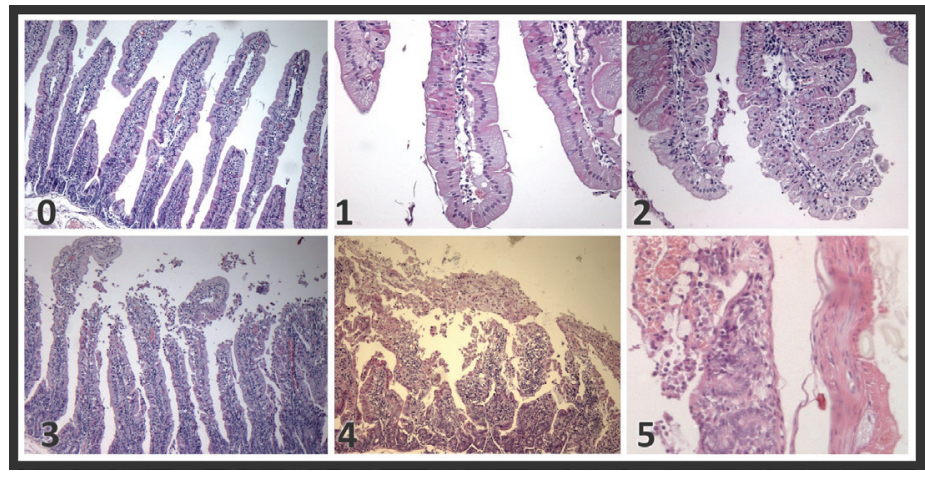

FIGURE 1 - Histopathology lesions intensity (Grade 0 to 5) classification.

\section{Results}

In the Group I animals, the followings histopathology grade results were observed: $t 1$, mean 2.8; 2 , mean 3.3. Using the Kruskal-Wallis non-parameter test, differences between t0 and $\mathrm{t} 1$ and $t 0$ and $t 2$ were significants $(p<0.05)$, but not significant between t1 and $\mathrm{t} 2(\mathrm{p}>0.05)$ (Table 1$)$.

In the Group 2 animals histopathology grade results were: $\mathrm{t} 1$ mean 2.6 and $\mathrm{t} 2$, mean 2.1. Differences between $\mathrm{t} 0$ and $\mathrm{t} 1, \mathrm{t} 0$ and t2 were significant $(\mathrm{p}<0.05)$ (Table 2, Figure 2).

It was not observed differences $(p>0.05)$ between results of $\mathrm{t} 1$ in both groups but histopathology injury observed in Group 1 t 2 biopsies were higher $(\mathrm{p}<0.05)$ than observed in the same period (t2) of Group 2 animals. 
TABLE 1 - Histopathology of Group 1 animals with ischemia without ischemic preconditioning.

$\begin{array}{lccccccccccc}\text { SAMPLES } \backslash \text { Obs. } \mathbf{N}^{\mathbf{0}} & \mathbf{1} & \mathbf{2} & \mathbf{3} & \mathbf{4} & \mathbf{5} & \mathbf{6} & \mathbf{7} & \mathbf{8} & \mathbf{9} & \mathbf{1 0} & \text { MEAN } \\ \mathrm{t}_{0}-\text { Control } & 0 & 0 & 0 & 0 & 0 & 0 & 0 & 0 & 0 & 0 & 0 \\ \mathrm{t}_{1}-\text { Ischemia 45, } & 2 & 3 & 3 & 3 & 3 & 4 & 3 & 2 & 3 & 2 & 2.8 \\ \mathrm{t}_{2}-\text { Reperfusion } 30 & 3 & 3 & 2 & 4 & 4 & 4 & 4 & 3 & 3 & 3 & 3.3\end{array}$

TABLE 2 - Histopathology of Group 2 animals with ischemic preconditioning.

$\begin{array}{lccccccccccc}\text { SAMPLES } \backslash \text { Obs. } \mathbf{N}^{\mathbf{0}} & \mathbf{1} & \mathbf{2} & \mathbf{3} & \mathbf{4} & \mathbf{5} & \mathbf{6} & \mathbf{7} & \mathbf{8} & \mathbf{9} & \mathbf{1 0} & \text { MEAN } \\ \mathrm{t}_{0}-\text { Control } & 0 & 0 & 0 & 0 & 0 & 0 & 0 & 0 & 0 & 0 & 0 \\ \mathrm{t}_{1}-\text { Ischemia 45, } & 2 & 3 & 2 & 2 & 2 & 3 & 3 & 2 & 4 & 3 & 2.6 \\ \mathrm{t}_{2}-\text { Reperfusion } 30 & 2 & 1 & 3 & 2 & 1 & 2 & 2 & 3 & 3 & 2 & 2.1\end{array}$

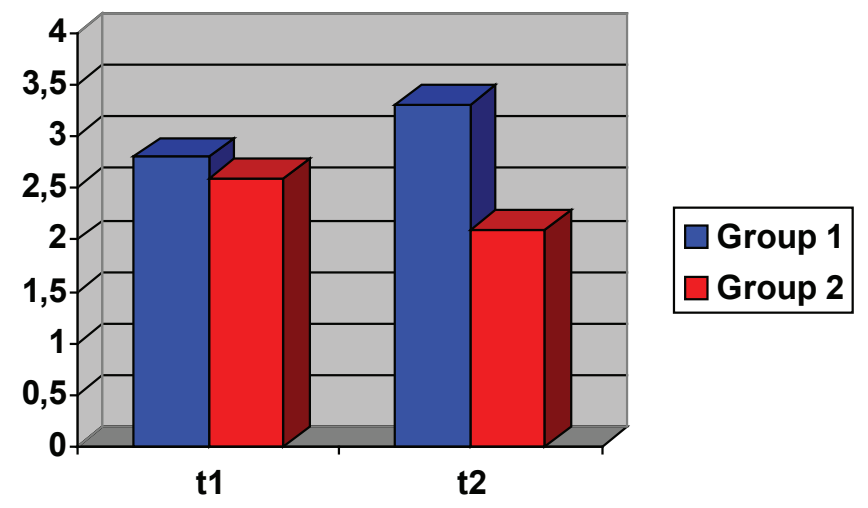

FIGURE 2 - Intestinal tissue lesion variation $\left({ }^{*} \mathrm{p}<0.05\right)$. t1 $-45 \mathrm{~min}$. ischemia t2-30 min. reperfusion. Group 1 - Without ischemic preconditioning. Group $2-$ With ischemic preconditioning.

\section{Discussion}

The mesenteric blood flow reduction and the ischemiareperfusion injury plays an important role in the pathogenesis and survival of many clinical and surgical diseases ${ }^{9-11}$, with important research approach done ${ }^{12-15}$ to understand the involved mechanisms aiming to obtain the best protection. Although confirmed in many researches, the pre and postconditioning failure to avoid the ischemia and ischemia-reperfusion lesions is also reported ${ }^{16-19}$, raising the respiratory dysfunction after cardiopulmonary bypass ${ }^{20}$ and to brain stroke events when induced by proton pump $\mathrm{Na}^{+} / \mathrm{H}^{+}$ATPase ${ }^{21}$.

This relative contradictory scenario regarding results with ischemic and or drug induced preconditioning was consistently recently studied by Ramzy et al. ${ }^{22}$ pointing the importance and benefits of new researches for best clinical results with pre and postconditioning. In this way it is very important to know the phenomenon behavior in different animal species opening new horizons to better understand the histology, physiology and biochemical mechanism of ischemia-reperfusion lesions and of the pre, post and remote preconditioning effect.
Introduced in the medicine universe by Murry et al. ${ }^{3}$, discovering the ischemic preconditioning protection in hearts of dogs submitted to temporary occlusion and reported to occur also in humans by Yellon et al. ${ }^{4}$, the occlusion by selective clamping of the cranial mesenteric artery in rats being the routine procedure until now in most reported mesenteric circulation research. Mesenteric Ischemia-reperfusion study in rabbits is rare and as reported by Bretz et $a l .{ }^{23}$ with different and bad protective results than observed with the mesenteric ischemic pre and postconditioning in rats.

In the present investigation, considering the particular anatomy of the mesenteric circulation in rabbits, previously reported ${ }^{24}$, for mesenteric ischemia induction in all animals the small bowel and mesentery were cut $30 \mathrm{~cm}$ and $60 \mathrm{~cm}$ far from the gastroduodenal pyloric transition before the proximal mesenteric artery occlusion thus avoiding the interference of the collateral circulation from the gastroduodenal arterial supply .

In the Group I animals, without ischemic preconditioning, the histopathology mean grade results were 2,8 after 45 minutes of mesenteric ischemia (t1) and mean 3,3 after $30 \mathrm{~min}$. of reperfusion (t2) without statistical significance between them. In the Group 2 animals, with ischemic preconditioning, histopathology mean grade results were 2.7 in $\mathrm{t} 1$ samples, significantly different from $\mathrm{t} 2$ with mean value of 2,3. Difference between $\mathrm{t} 1$ results in both groups was not significant $(\mathrm{p}>0.05)$ but post ischemia reperfusion injury ( $\mathrm{t} 2)$ in Group 2 animals was significantly lower than observed in Group 1.

Although with limited results interpretation mainly by considering only one period of induced mesenteric ischemia and only one sequence of the ischemia and reperfusion periods for the preconditioning induction it was demonstrated by this investigation in rabbits best significant protection by the ischemic preconditioning against the ischemia reperfusion injury than observed with the ischemia before reperfusion beginning.

\section{Conclusion}

The obtained results leads to the conclusion that microscopic examination of the biopsies revealed significant evidence of preconditioning protection against small bowel wall ischemia-reperfusion injury.

\section{References}

1. Parks DA, Granger DN. Contributions of ischemia and reperfusion to mucosal lesion formation. Am J Physiol. 1986;250:749-53.

2. Murry CE, Jennings RB, Reimer KA. Preconditioning with ischemia: a delay of lethal cell injury in ischemic myocardium. Circulation. 1986;74(5):1124-36.

3. Yellon DM, Alkhulaifi AM, Pugsley WB. Preconditioning the human myocardium. Lancet. 1993;342:276-7.

4. Hotter G, Closa D, Prados M, Fernandez-Cruz L, Prats N, Gelpi E, Roselló-Catafau J. Intestinal preconditioning is mediated by a transient increase in nitric oxide. Biochem Biophys Res Commun. 1996;222(1):27-32.

5. Santos CHM, Gomes OM, Pontes JCDV, Miiji LNO, Bispo MA. The ischemic preconditioning and postconditioning effect on the intestinal mucosa of rats undergoing mesenteric ischemia/reperfusion process. Acta Cir Bras. 2008;23(1):22-8.

6. Bretz B, Blaze C, Parry N, Kudej RK. Ischemic postconditioning does 
not attenuate ischemia-reperfusion injury of rabbit small intestine. Vet Surg. 2010;39(2):216-3.

7. Gomes OM, Brasileiro Filho G, Porto LAB, Prata PHL, Paixão R. $\mathrm{M}$. Ischemia reperfusion histopathology alterations of the rabbit intestinal wall with and without exclusion of the collateral mesenteric circulation supply, Acta Cir Bras. 2010;25(4);318-21.

8. Chiu CJ, McArdle AH, Brown R, Scott HJ, Gurd FN. Intestinal mucosal lesion in low-flow states. Arch Surg. 1970;101:478-83.

9. Khanna A, Rossman JE, Fung HL, Caty MG. Intestinal and hemodynamic impairment following mesenteric ischemia/ reperfusion. J Surg Res. 2001;99:114-9.

10. Zhou JL, Jin GH, Yi YL, Zhang JL, Huang XL. Role of nitric oxide and peroxynitrite anion in injury induced by intestinal ischemiareperfusion in rats. World J Gastroenterol. 2003;9:1318-26.

11. Arakawa K, Takeyoshi I, Muraoka M, Matsumoto K, MorishitaY. Measuring platelet aggregation to estimate small intestinal ischemiareperfusion injury. J Surg Res. 2004;122:195-202.

12. Mallick H, Yang WX, Winslet MC, Seifalian AM. Ischemiareperfusion injury of the intestine and protective strategies against injury. Dig Dis Sci. 2004;49;1359-65.

13. Santos CHM, Gomes OM, Pontes JCDV, Miiji LNO, Higa EI. Uso do propofol (2,6 diisopropilfenol) como inibidor da lesão tecidual na isquemia e reperfusão mesentérica. Estudo experimental em ratos. Acta Cir Bras. 2003; 18:347-54.

14. Ribeiro ME, Yoshida WB. Reperfusion injury after intestinal ischemia: pathophysiology and experimental models. J Vasc Br. 2005;4(2):18394.

15. Santos CHM, Gomes OM, Pontes JCDV. Terapêutica medicamentosa na isquemia e reperfusão mesentérica: revisão da literatura. Rev Bras Coloproctol. 2006;26:28-33.

16. Cremer J, Steinhoff G, Karck M, Ahnsell T, Brandt M, Teebken $\mathrm{OE}$, Hollander D, Haverich A. Ischemic preconditioning prior to myocardial protection with cold blood cardioplegia in coronary surgery. Eur J Cardiothorac Surg. 1997;12(5):753-8.
17. Pêgo-Fernandes PM, Jatene FB, Kwasnicka K, Hueb AC, Moreira LF, Gentil AF, Stolf NA, Oliveira SA. Ischemic preconditioning in myocardial revascularization with intermittent aortic cross-clamping. J Card Surg. 2000;15(5):333-8.

18. Perrault LP, Menasché P, Bel A, de Chaumaray T. Peynet J, Mondry A, Olivero P, Emanoil-Ravier R, Moalic JM. Ischemic preconditioning in cardiac surgery: a word of caution. J Thorac Cardiovasc Surg. 1996;112(5):1378-86.

19. Illes RW, Swoyer KD. Prospective, randomized clinical study of ischemic preconditioning as an adjunct to intermittent cold blood cardioplegia. Ann Thorac Surg. 1998;65:748-52.

20. Eichler W, Bechtel MJF, Klaus S, Heringlake M, Hernandez M, Toerber K, Klotz K-F, Bartels C. Na+/H+exchange inhibitor cariporide: effects on respiratory dysfunction after cardiopulmonary bypass. Perfusion. 2004;19(1):33-40.

21. Gruberg L. EXPEDITION: Sodium-Proton Exchange Inhibition to Prevent Coronary Events in Acute Cardiac Conditions Tri. http:// www.medscape.com/viewarticle/464672

22. Ramzy D, Rao V, Weisel RD. Clinical applicability of preconditioning and postconditioning: The cardiothoracic surgeons's view. Cardiovasc Res. 2006;70(2):174-80.

23. Bretz B, Blaze C,Parry N, Kudej RK. Ischemic postconditioning does not attenuate ischemia-reperfusion injury of rabbit small intestine. Vet Surg. 2010;39(2):216-23.

24. Gomes OM, Brasileiro Filho G, Porto LAB, Prata PHL, Paixão RM. Ischemia-reperfusion histopathology alterations of the rabbit intestinal wall with and without exclusion of the collateral mesenteric circulation supply. Acta Cir Bras. 2010;25(4):318-21

\section{Correspondence:}

Otoni Moreira Gomes

Av. Sanitária Dois, 12

31530-000 Belo Horizonte - MG Brasil

Tel/Fax: (55 31)3439-3004

gomes@servcor.com
Conflict of interest: none Financial source: none

Received: December 15, 2010 Review: February 17, 2011 Accepted: March 18, 2011 